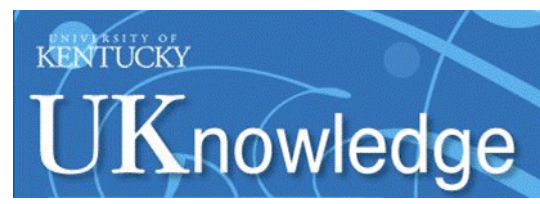

University of Kentucky UKnowledge

7-2008

\title{
Nitrite Reduction by Siderite
}

\author{
Sudipta Rakshit \\ University of California, Berkeley \\ Christopher J. Matocha \\ University of Kentucky, cjmato2@uky.edu \\ Mark S. Coyne \\ University of Kentucky, mark.coyne@uky.edu
}

Follow this and additional works at: https://uknowledge.uky.edu/pss_facpub

Part of the Plant Sciences Commons

Right click to open a feedback form in a new tab to let us know how this document benefits you.

\section{Repository Citation}

Rakshit, Sudipta; Matocha, Christopher J.; and Coyne, Mark S., "Nitrite Reduction by Siderite" (2008). Plant and Soil Sciences Faculty Publications. 2.

https://uknowledge.uky.edu/pss_facpub/2

This Article is brought to you for free and open access by the Plant and Soil Sciences at UKnowledge. It has been accepted for inclusion in Plant and Soil Sciences Faculty Publications by an authorized administrator of UKnowledge. For more information, please contact UKnowledge@lsv.uky.edu. 
Nitrite Reduction by Siderite

Digital Object Identifier (DOI)

http://dx.doi.org/10.2136/sssaj2007.0296

Notes/Citation Information

Published in Soil Science Society of America Journal, v. 72, no. 4, p. 1070-1077.

The copyright holder has granted permission for posting the article here.

This article is available at UKnowledge: https://uknowledge.uky.edu/pss_facpub/2 


\section{Nitrite Reduction by Siderite}

\author{
Sudipta Rakshit \\ ESPM \\ Division of Ecosystem Sciences \\ 140 Mulford Hall \\ Univ. of California \\ Berkeley, CA 94720
Christopher J. Matocha* Mark S. Coyne
Dep. of Plant and Soil Sciences
Univ. of Kentucky
$\mathrm{N}-122 \mathrm{R}$ Agricultural Science Building-North
Lexington, KY 40546-0091

\begin{abstract}
Nitrate-dependent Fe(II) oxidation is an important process in the inhibition of soil Fe(III) reduction, yet the mechanisms are poorly understood. One proposed pathway includes chemical reoxidation of mineral forms of $\mathrm{Fe}(\mathrm{II})$ such as siderite $\left[\mathrm{FeCO}_{3(\mathrm{~s})}\right]$ by $\mathrm{NO}_{2}{ }^{-}$. Accordingly, the objective of this study was to investigate the reactivity of $\mathrm{FeCO}_{3(\mathrm{~s})}$ with $\mathrm{NO}_{2}{ }^{-}$. Stirredbatch reactions were performed in an anoxic chamber across a range of $\mathrm{pH}$ values $(5.5,6,6.5$, and 7.9), initial $\mathrm{FeCO}_{3(\mathrm{~s})}$ concentrations (5, 10, and $15 \mathrm{~g} \mathrm{~L}^{-1}$ ) and initial $\mathrm{NO}_{2}{ }^{-}$concentrations $\left(0.83-9.3 \mathrm{mmol} \mathrm{L}^{-1}\right)$ for kinetic and stoichiometric determinations. Solid-phase products were characterized using $\mathrm{x}$-ray diffraction (XRD). Siderite abiotically reduced $\mathrm{NO}_{2}{ }^{-}$to $\mathrm{N}_{2} \mathrm{O}$. During the process, $\mathrm{FeCO}_{3(s)}$ was oxidized to lepidocrocite $\left[\gamma-\mathrm{FeOOH}_{(s)}\right]$ based on the appearance of XRD peaks located at $0.624,0.329$, and $0.247 \mathrm{~nm}$. The rate of $\mathrm{NO}_{2}^{-}$ reduction was first order in total $\mathrm{NO}_{2}{ }^{-}$concentration and $\mathrm{FeCO}_{3(\mathrm{~s})}$, with a second-order rate coefficient $(\mathrm{k})$ of $0.55 \pm 0.05 \mathrm{M}^{-1} \mathrm{~h}^{-1}$ at $\mathrm{pH} 5.5$ and $25^{\circ} \mathrm{C}$. The reaction was proton assisted and $\mathrm{k}$ values increased threefold as $\mathrm{pH}$ decreased from 7.9 to 5.5. The influence of $\mathrm{pH}$ on $\mathrm{NO}_{2}{ }^{-}$reduction was rationalized in terms of the availability of $\mathrm{FeCO}_{3(s)}$ surface sites $\left(>\mathrm{FeHCO}_{3}{ }^{0},>\mathrm{FeOH}_{2}{ }^{+}\right.$, and $>\mathrm{CO}_{3} \mathrm{Fe}^{+}$) and $\mathrm{HNO}_{2}$ concentration. These findings indicate that if $\mathrm{FeCO}_{3(s)}$ is present in an $\mathrm{Fe}(\mathrm{III})$-reducing soil where fertilizer $\mathrm{NO}_{3}{ }^{-}$is applied, it can participate in secondary chemical reactions with $\mathrm{NO}_{2}{ }^{-}$and lead to an inhibition in $\mathrm{Fe}$ (III) reduction. This process is relevant in soil environments where $\mathrm{NO}_{3}{ }^{-}$- and $\mathrm{Fe}$ (III)-reducing zones overlap or across aerobic-anaerobic interfaces.
\end{abstract}

Abbreviations: XRD, x-ray diffraction.
$\mathrm{I}_{\mathrm{is}}^{\mathrm{rom}}$

ron is the fourth most abundant element in mineral soils and is subject to changes in oxidation state (Essington, 2004). Microbial $\mathrm{Fe}(\mathrm{III})$ reduction to $\mathrm{Fe}(\mathrm{II})$ is an important process in anoxic soil environments because of its influence on organic C oxidation, soil physicochemical properties, and contaminant mobility (Lovley, 2000; Favre et al., 2002). During reduction of $\mathrm{Fe}$ (III) (oxy)hydroxides or phyllosilicate $\mathrm{Fe}(\mathrm{III}), \mathrm{Fe}$ (II) is released to solution and can undergo secondary processes such as adsorption and precipitation.

Siderite $\left[\mathrm{FeCO}_{3(\mathrm{~s})}\right]$ is a common $\mathrm{Fe}(\mathrm{II})$ mineral produced as a result of secondary precipitation during microbial Fe(III) reduction under anoxic conditions (Coleman et al., 1993; Fredrickson et al., 1998; Zachara et al., 1998; Williams et al., 2005). Siderite has been shown to control Fe(II) solubility in anoxic sediments (Suess, 1979; Postma, 1982), rice paddy soil (Ratering and Schnell, 2000), subsoil peat horizons in close association with plant material (McMillan and Schwertmann, 1998), and coal overburden (Frisbee and Hossner, 1995; Haney et al.,2006). Oxidants for $\mathrm{FeCO}_{3(\mathrm{~s})}$ include $\mathrm{O}_{2}$ (Frisbee and Hossner, 1995; Duckworth and Martin, 2004), Cr(VI) (Wilkin

Soil Sci. Soc. Am. J. 72:1070-1077

doi:10.2136/sssaj2007.0296

Received 10 Aug. 2007.

*Corresponding author (cjmato2@uky.edu).

(c) Soil Science Society of America

677 S. Segoe Rd. Madison WI 53711 USA

All rights reserved. No part of this periodical may be reproduced or transmitted in any form or by any means, electronic or mechanical, including photocopying, recording, or any information storage and retrieval system, without permission in writing from the publisher. Permission for printing and for reprinting the material contained herein has been obtained by the publisher. et al., 2005), $\mathrm{H}_{2} \mathrm{O}_{2}$ (Jambor et al., 2003), and $\mathrm{KMnO}_{4}$ (Haney et al., 2006).

Nitrate inhibits $\mathrm{Fe}$ (III) reduction to $\mathrm{Fe}(\mathrm{II})$ in soils and sediments (Sorensen, 1982; Lovley, 2000). One explanation for this inhibition is $\mathrm{NO}_{3}{ }^{-}$-dependent $\mathrm{Fe}(\mathrm{II})$ oxidation, resulting in the anoxic production of Fe(III) (Lovley, 2000). Environments where $\mathrm{NO}_{3}{ }^{-}$-dependent $\mathrm{Fe}(\mathrm{II})$ oxidation is important include zones where $\mathrm{NO}_{3}{ }^{-}$reduction and $\mathrm{Fe}(\mathrm{III})$ reduction overlap (Weber et al., 2006). Concurrent $\mathrm{NO}_{3}{ }^{-}$ and $\mathrm{Fe}$ (III)-reducing zones have been reported in laboratory incubations of field soils and pure cultures (Komatsu et al., 1978; Obuekwe et al., 1981; DiChristina, 1992). Where concomitant $\mathrm{NO}_{3}{ }^{-}$and $\mathrm{Fe}(\mathrm{III})$ reduction occur, the biologically produced $\mathrm{Fe}(\mathrm{II})$ and $\mathrm{NO}_{2}{ }^{-}$can react chemically, producing $\mathrm{Fe}$ (III) and $\mathrm{N}_{2} \mathrm{O}$ (Moraghan and Buresh, 1977). The Fe(III) product resulting from solution $\mathrm{Fe}(\mathrm{II})$ oxidation by $\mathrm{NO}_{2}{ }^{-}$was shown to be a poorly crystalline $\mathrm{Fe}$ (III) oxide mineral that was capable of affecting U cycling (Senko et al., 2005). The $\mathrm{Fe}(\mathrm{II})-\mathrm{NO}_{2}{ }^{-}$chemical process has been invoked to explain the apparent inhibition of $\mathrm{Fe}(\mathrm{III})$ reduction in the presence of $\mathrm{NO}_{3}{ }^{-}$in pure cultures (Obuekwe et al., 1981) and anoxic paddy soil slurries (Komatsu et al., 1978). Cleemput and Baert (1983) showed that this reaction was more rapid as $\mathrm{pH}$ decreased. This may be attributed to the greater proportion of $\mathrm{HNO}_{2}$ species. Protonation promotes $\mathrm{N}-\mathrm{O}$ bond breaking, thus $\mathrm{HNO}_{2}$ is a stronger oxidant than $\mathrm{NO}_{2}^{-}$(Shriver et al., 1994). The presence of mineral surfaces such as Fe(III) (hydr) oxide minerals can readsorb Fe(II), leading to an acceleration in the electron transfer reaction rate to $\mathrm{NO}_{2}{ }^{-}$because surface $\mathrm{Fe}(\mathrm{II})$ is more reactive than dissolved $\mathrm{Fe}(\mathrm{II})$ (Sorensen and Thorling, 1991; Cooper et al., 2003).

Previously, $\mathrm{NO}_{3}{ }^{-}$was added to an agricultural surface soil under $\mathrm{Fe}(\mathrm{III})$-reducing conditions and $\mathrm{NO}_{3}{ }^{-}$-dependent 
Fe(II) oxidation occurred (Matocha and Coyne, 2007). It was suggested that this process was due in part to chemical reoxidation of mineral-associated $\mathrm{Fe}$ (II) by $\mathrm{NO}_{2}^{-}$. One possible $\mathrm{Fe}(\mathrm{II})$ mineral that may have formed was $\mathrm{FeCO}_{3(\mathrm{~s})}$ based on thermodynamic modeling of soil filtrates; however, the role of $\mathrm{FeCO}_{3(\mathrm{~s})}$ in $\mathrm{NO}_{2}{ }^{-}$reduction is unclear. One could anticipate reduction of $\mathrm{NO}_{2}^{-}$by $\mathrm{FeCO}_{3(\mathrm{~s})}$ because the redox couples for $\mathrm{FeCO}_{3(\mathrm{~s})}$ and oxidized $\mathrm{Fe}$ (III) minerals [such as lepidocrocite, $\left.\gamma-\mathrm{FeOOH}_{(\mathrm{s})}\right]$ lie well below that of $\mathrm{NO}_{2}{ }^{-}-\mathrm{N}_{2} \mathrm{O}$ (Fig. 1). This indicates that a thermodynamic driving force exists for the reaction to proceed. For $\mathrm{FeCO}_{3(\mathrm{~s})}$ to be important, one requirement is that it precipitate at relevant time scales. Siderite fulfills this requirement because precipitation is rapid, nearing completion within $4 \mathrm{~h}$ in the laboratory (Thornber and Nickel, 1976). Past studies have shown that mineral Fe(II) in wüstite $\left[\mathrm{FeO}_{(\mathrm{s})}\right]$ and green rust can readily reduce $\mathrm{NO}_{2}{ }^{-}$(Hansen et al., 1994; Rakshit et al., 2005) as well as Fe(II) bound on lepidocrocite (Sorensen and Thorling, 1991). Thus, the objective of this study was to investigate the reactivity of $\mathrm{NO}_{2}{ }^{-}$with siderite as a function of $\mathrm{pH}$ and reactant concentrations under anoxic conditions.

\section{MATERIALS AND METHODS \\ Siderite Synthesis and Characterization}

All the solutions were prepared using deionized water $(18 \Omega)$ that was made anoxic by purging with Ar for $3 \mathrm{~h}$. To ensure anoxic environments, siderite synthesis and reactivity studies were conducted in an $\mathrm{Ar}-\mathrm{H}_{2}$ purged anaerobic chamber (Coy Laboratory Products, Grass Lake, MI). Siderite was synthesized by adding $\mathrm{Na}_{2} \mathrm{CO}_{3}$ to a stirred 0.5 - $\mathrm{L}$ solution of $\mathrm{FeCl}_{2}$ in equimolar amounts $\left(0.5 \mathrm{~mol} \mathrm{~L}^{-1}\right)$ to form a pale gray precipitate, as described by Thamdrup et al. (1993). The siderite precipitate was washed with anoxic water to remove salts until the electrical conductivity of the wash water was lowered to background levels. The washed siderite was stored in suspension. The solid concentration of the siderite suspension was determined by weighing replicate subsamples. Subsamples of siderite were removed for characterization of alkalinity and solution $\mathrm{Fe}(\mathrm{II})$ at the native $\mathrm{pH}$ of the washed siderite $(\mathrm{pH} 8.0)$ and at $\mathrm{pH}$ 6.0. The $\mathrm{pH}$ and alkalinity values were used to calculate total carbonate concentration using MINEQL+ (Schecher and McAvoy, 1998), assuming a system closed to atmospheric $\mathrm{CO}_{2}$. Solution $\mathrm{Fe}(\mathrm{II})$ was measured using the ferrozine [3-(2-pyridyl)-5,6 bis(4-phenylsulfonic acid)-1,2,4-triazine, monosodium salt] method by following absorbance at a wavelength of 562 $\mathrm{nm}$ (Stookey, 1970) with a ultraviolet-visible-near-infrared scanning spectrophotometer (Shimadzu, UV-3101 PC, Columbia, MD).

$\mathrm{X}$-ray diffraction was used to characterize the gray precipitate. A slurry of the siderite mineral was mixed with Ar-degassed glycerol to prevent $\mathrm{Fe}$ (II) oxidation and dried under Ar. Scans were taken from 2 to $80^{\circ} 2 \theta$ with $\mathrm{CuK \alpha}$ radiation using a Siemens D-500 powder diffractometer fitted with a graphite monochromator and $\mathrm{NaI}$ (Tl) scintillation detector. The XRD peaks located at $0.359,0.279,0.234$, $0.213,0.196,0.179,0.173,0.152$, and $0.144 \mathrm{~nm}$ confirmed the presence of siderite (Sharp, 1960).

\section{Stirred-Batch Experiments}

Stock solutions of $\mathrm{NO}_{2}{ }^{-}$were prepared by dissolving certified ACS-grade $\mathrm{NaNO}_{2}$ in deoxygenated, deionized water in a glove box. Reactions were performed in stirred-batch mode in duplicate $30-\mathrm{mL}$ glass bottles. Experiments were initiated by adding aliquots of $\mathrm{NO}_{2}{ }^{-}$ from the stock solution to the stirred siderite suspensions. In one set of experiments designed to evaluate the influence of initial $\mathrm{FeCO}_{3(\mathrm{~s})}$ concentration on the rate of $\mathrm{NO}_{2}{ }^{-}$reduction, $\mathrm{FeCO}_{3(\mathrm{~s})}$ was varied between 5 and $15 \mathrm{~g} \mathrm{FeCO}_{3(\mathrm{~s})} \mathrm{L}^{-1}$ [corresponding to $\mathrm{Fe}(\mathrm{II})$ concentrations of $0.04-0.12 \mathrm{~mol} \mathrm{~L}^{-1}$, while $\mathrm{NO}_{2}{ }^{-}$concentration was held constant $\left(4.6 \mathrm{mmol} \mathrm{L}^{-1}\right)$ at $\mathrm{pH}$ 5.5. In another set of experiments, the initial $\mathrm{NO}_{2}^{-}$was varied between 0.83 and $9.3 \mathrm{mmol} \mathrm{L}{ }^{-1}$ at a constant $\mathrm{FeCO}_{3(\mathrm{~s})}$ concentration of $10 \mathrm{~g} \mathrm{~L}^{-1}$ at $\mathrm{pH}$ 5.5. In addition, the rate of $\mathrm{NO}_{2}{ }^{-}$reduction was followed at $\mathrm{pH} \mathrm{6.0,} \mathrm{6.5,} \mathrm{and} \mathrm{7.9.}$ The biological buffers MES [2-( $N$-morpholino)ethane sulfonic acid], PIPES (1,4-piperazine diethane sulfonic acid), and HEPES [1-piperazineethane sulfonic acid, 4-(2-hydroxyethyl)-monosodium salt] with concentrations of $0.3 \mathrm{~mol} \mathrm{~L}^{-1}$ were added to control the $\mathrm{pH}$ (Alowitz and Scherer, 2002). The $\mathrm{pH}$ was monitored periodically and found constant throughout the experiment. All experiments were conducted at $25^{\circ} \mathrm{C}$.

Blank experiments were performed $\left[\mathrm{FeCO}_{3(\mathrm{~s})}\right.$ free] by shaking $4.6 \mathrm{mmol} \mathrm{L}^{-1} \mathrm{NO}_{2}{ }^{-}$in MES at $\mathrm{pH} 5.5$ to account for possible selfdecomposition of $\mathrm{NO}_{2}{ }^{-}$(Cleemput and Baert, 1983). We performed another experiment in which $4.6 \mathrm{mmol} \mathrm{L}^{-1} \mathrm{NO}_{2}{ }^{-}$was added to dissolved $\mathrm{Fe}(\mathrm{II})$ extracted from the dissolving $\mathrm{FeCO}_{3(\mathrm{~s})}$ mineral to determine if dissolved $\mathrm{Fe}$ (II) could be responsible for the reaction. This experiment is referred to as "dissolved Fe(II)." Suspensions were removed periodically and filtered through a $0.2-\mu \mathrm{m}$ membrane filter (Fisher Scientific, Hampton, NH). Ferrozine was added to the filtrates to complex and quantify dissolved Fe(II). The residue on the filter paper was washed with anoxic water to remove any $\mathrm{NO}_{2}{ }^{-}$present and treated with $0.5 \mathrm{~mol} \mathrm{~L}^{-1} \mathrm{HCl}$ to dissolve $\mathrm{Fe}(\mathrm{II})$ present in the solid phase. The moles of solid-phase Fe(II) reacted were determined by comparing the $\mathrm{Fe}$ (II) concentrations in the solution and solid phases of reacted samples with that of a control $\mathrm{FeCO}_{3(\mathrm{~s})}$ experiment $\left(\mathrm{NO}_{2}{ }^{-}\right.$free).

Nitrite concentration was measured using a Metrohm 792 Basic ion chromatograph (Herisau, Switzerland) with a MetroSep A column and MetroSep RP guard disk holder. The eluent was a mixture of $3.2 \mathrm{mmol} \mathrm{L}-1 \mathrm{Na}_{2} \mathrm{CO}_{3}$ and $1 \mathrm{mmol} \mathrm{L}^{-1} \mathrm{HCO}_{3}{ }^{-}$with conductivity detection. The retention time for $\mathrm{NO}_{2}^{-}$was 6 min. The indophenol-blue method (Ngo et al., 1982) was used to measure $\mathrm{NH}_{4}{ }^{+}$. In separate experiments, $\mathrm{N}_{2} \mathrm{O}$ was measured in the head space of capped

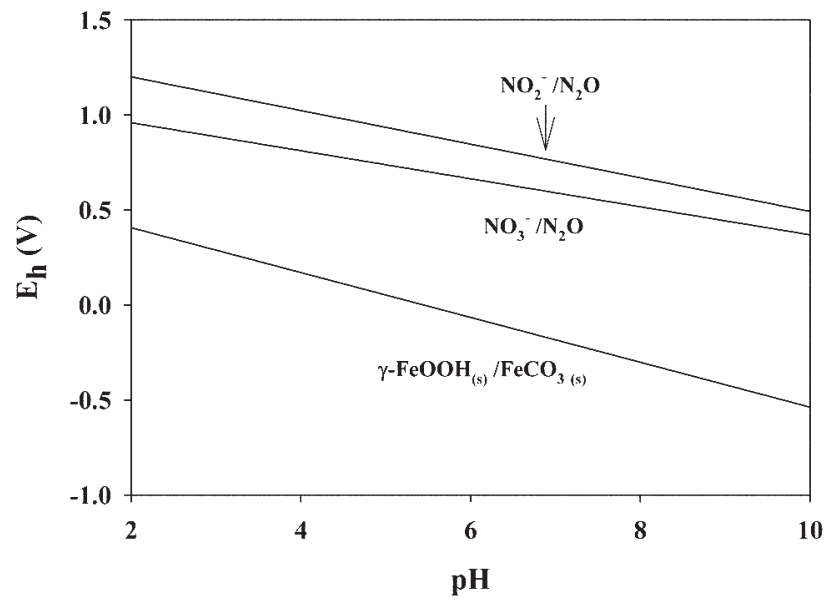

Fig. 1. A redox potential $\left(E_{h}\right)-p H$ diagram for the $\mathrm{N}-\mathrm{Fe}$ system. The concentration of solution $\mathrm{NO}_{3}{ }^{-}$and $\mathrm{NO}_{2}{ }^{-}$was taken to be $0.004 \mathrm{~mol} \mathrm{~L}^{-1}$. The concentration of $\mathrm{N}_{2} \mathrm{O}$ was $0.0003 \mathrm{~mol} \mathrm{~L}^{-1}$. Standard reduction potentials $\left(\mathrm{Eh}^{0}\right)$ for the $\mathrm{NO}_{2}{ }^{-}-\mathrm{N}_{2} \mathrm{O}$ and $\mathrm{NO}_{3}{ }^{-}-\mathrm{N}_{2} \mathrm{O}$ couples were 1.396 and $1.116 \mathrm{~V}$, respectively (Bard et al., 1985). The $\mathrm{Eh}^{0}$ for the $\gamma-\mathrm{FeOOH}_{(\mathrm{s})}-\mathrm{FeCO}_{3(\mathrm{~s})}$ couple was estimated from Gibbs free energy of formation values to be $0.86 \mathrm{~V}$. 
30-mL glass vials using a Varian 3700 gas chromatograph with a 2 mol L ${ }^{-1}$ packed column, Porapak Q, with a thermal conductivity detector and $20 \mathrm{~mL} \mathrm{~min}^{-1} \mathrm{He}$ carrier gas.

Solid-phase reaction products were collected for samples reacted with $4.6 \mathrm{mmol} \mathrm{L}^{-1} \mathrm{NO}_{2}^{-}$for 24 and $96 \mathrm{~h}$ and compared with a control siderite sample. Slurries were mixed with glycerol, dried, and $\mathrm{XRD}$ was performed as described above.

\section{RESULTS AND DISCUSSION Stoichiometry}

Siderite readily reduced $\mathrm{NO}_{2}{ }^{-}$(Fig. $2 \mathrm{~A}-2 \mathrm{C}$ ). For example, approximately $60 \%$ of the initial $\mathrm{NO}_{2}{ }^{-}$was lost from solution after $23 \mathrm{~h}$ at $\mathrm{pH} 5.5$ and initial $\mathrm{NO}_{2}{ }^{-}$and $\mathrm{FeCO}_{3(\mathrm{~s})}$ levels of $4.6 \mathrm{mmol} \mathrm{L}^{-1}$ and $10 \mathrm{~g} \mathrm{~L}^{-1}$ (Fig. 2A). No significant $\mathrm{NO}_{2}{ }^{-}$ loss occurred in the blank experiments $\left[\mathrm{FeCO}_{3(\mathrm{~s})}\right.$ free] at $\mathrm{pH}$
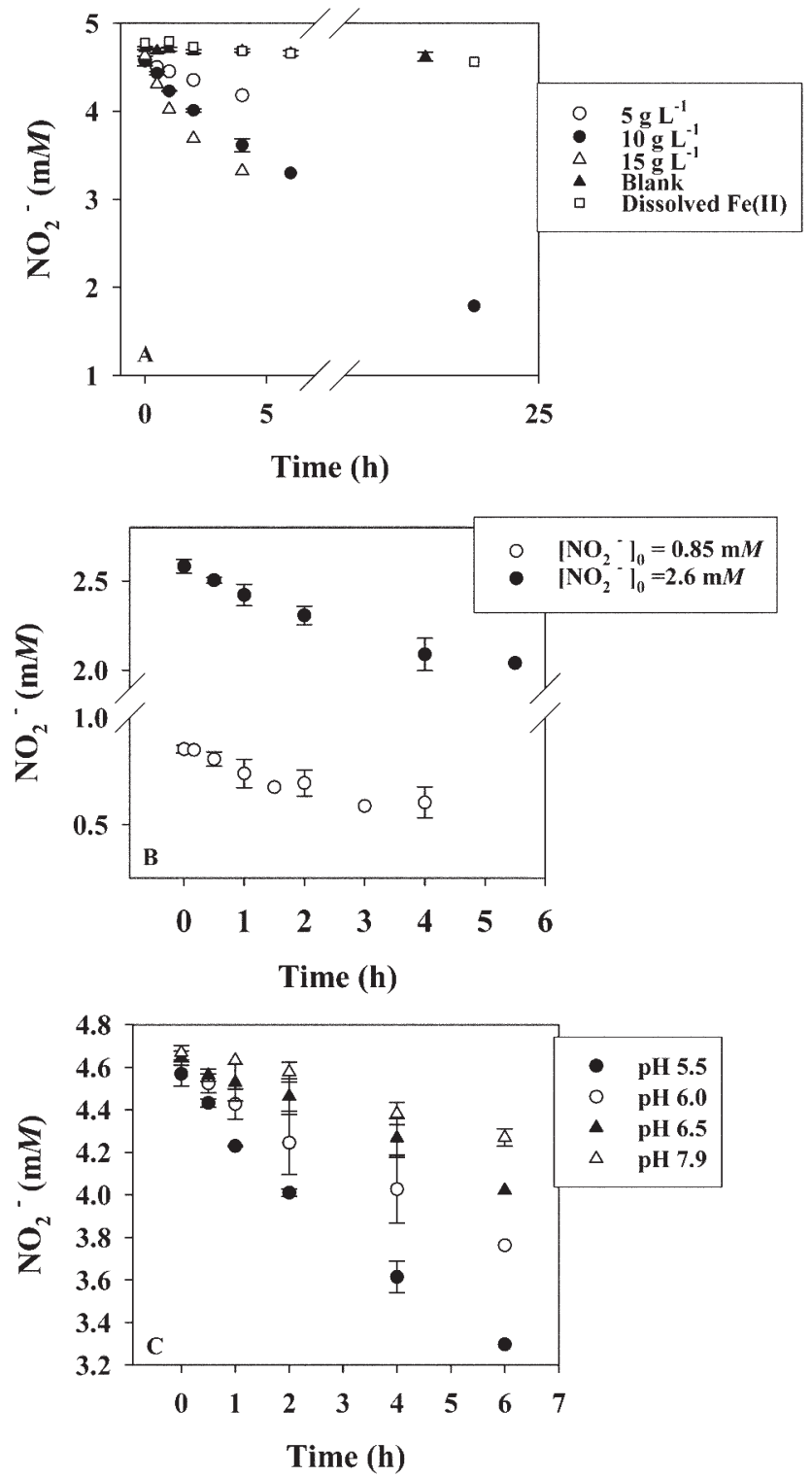

Fig. 2. Time course of $\mathrm{NO}_{2}^{-}$reduction at (A) varying siderite level $\left(5,10\right.$, and $\left.15 \mathrm{~g} \mathrm{~L}^{-1}\right)$ compared with a blank (siderite free) and dissolved $\mathrm{Fe}$ (II) sample with an initial $\mathrm{NO}_{2}{ }^{-}$concentration of $4.6 \mathrm{mmol} \mathrm{L}^{-1}$ at $\mathrm{pH}$ 5.5; (B) varying initial $\mathrm{NO}_{2}^{-}$concentration at $\mathrm{pH} 5.5$ and a siderite concentration of $10 \mathrm{~g} \mathrm{~L}^{-1}$; and (C) varying $\mathrm{pH}$ values, with a siderite concentration of $10 \mathrm{~g} \mathrm{~L}^{-1}$ and $\mathrm{NO}_{2}^{-}$of $4.6 \mathrm{mmol} \mathrm{L}^{-1}$. Error bars represent the standard deviation from the mean for duplicate runs.
5.5 during the same time frame. This rules out self-decomposition of $\mathrm{NO}_{2}{ }^{-}$. Past studies have shown self-decomposition of $\mathrm{NO}_{2}{ }^{-}$to be important at $\mathrm{pH}<5.0$ (Bartlett, 1981). The major product identified for $\mathrm{NO}_{2}{ }^{-}$reduction was $\mathrm{N}_{2} \mathrm{O}$ based on gas chromatography. $\mathrm{No} \mathrm{NH}_{4}^{+}$was detected. Wet chemical extractions of Fe(II) showed that $0.50 \pm 0.25 \mathrm{mmol} \mathrm{L}^{-1}$ was oxidized and $0.24 \pm 0.1 \mathrm{mmol} \mathrm{L}^{-1}$ of $\mathrm{NO}_{2}^{-}$was reduced after $1 \mathrm{~h}$ of reaction time in experiments containing $10 \mathrm{~g} \mathrm{~L}^{-1} \mathrm{FeCO}_{3(\mathrm{~s})}$ and $4.6 \mathrm{mmol} \mathrm{L}^{-1} \mathrm{NO}_{2}^{-}$(Fig. 2A). This indicates a 2:1 consumption of $\mathrm{Fe}(\mathrm{II})$ per mole of $\mathrm{NO}_{2}{ }^{-}$reduced and is consistent with the formation of $\mathrm{N}_{2} \mathrm{O}$ as the major product of $\mathrm{NO}_{2}{ }^{-}$reduction. Similarly, Sorensen and Thorling (1991) found $\mathrm{N}_{2} \mathrm{O}$ as the major product of $\mathrm{NO}_{2}{ }^{-}$reduction in the presence of $\mathrm{Fe}(\mathrm{II})$ bound to lepidocrocite. Hansen et al. (1994) reported production of $\mathrm{N}_{2} \mathrm{O}$ during reduction of $\mathrm{NO}_{2}{ }^{-}$by green rust.

Solid-phase products were characterized using XRD in reacted and control $\left(\mathrm{NO}_{2}{ }^{-}\right.$free $)$samples. The diagnostic $\mathrm{d}$-spacings at $0.359,0.279,0.234,0.213,0.196,0.179,0.173$, 0.152 , and $0.144 \mathrm{~nm}$ revealed that $\mathrm{FeCO}_{3(\mathrm{~s})}$ was the sole mineral present after $96 \mathrm{~h}$ in control experiments (Fig. 3a). Siderite reacted with $\mathrm{NO}_{2}{ }^{-}$under identical conditions as in Fig. 2A $\left[10 \mathrm{~g} \mathrm{~L}^{-1} \mathrm{FeCO}_{3(\mathrm{~s})}, 4.6 \mathrm{mmol} \mathrm{L}^{-1} \mathrm{NO}_{2}{ }^{-}, \mathrm{pH}\right.$ 5.5] showed a decrease in the intensity of the 104 reflection at $0.279 \mathrm{~nm}$ and the 116 reflection at $0.173 \mathrm{~nm}$ after $24 \mathrm{~h}$ of reaction (Fig. $3 \mathrm{~b}$ ), where approximately $2.8 \mathrm{mmol} \mathrm{L}^{-1} \mathrm{NO}_{2}{ }^{-}$was reduced (Fig. $2 \mathrm{~A})$. At longer times $(96 \mathrm{~h})$ in the $\mathrm{NO}_{2}{ }^{-}$-reacted samples, the appearance of peaks at $0.624,0.329$, and $0.247 \mathrm{~nm}$ indicated the production of lepidocrocite $\left[\gamma-\mathrm{FeOOH}_{(s)}\right]$ (Fig. 3c). The weak feature at $0.173 \mathrm{~nm}$ could represent unreacted siderite or the 151 reflection of lepidocrocite. In addition to the lepidocrocite peaks, one diffraction peak was observed for goethite $\left[\alpha-\mathrm{FeOOH}_{(\mathrm{s})}\right]$ at $0.420 \mathrm{~nm}$.

Past studies have documented the important role of $\mathrm{O}_{2}$ in siderite oxidation. Resulting oxidation products include ferrihydrite (Duckworth and Martin, 2004), lepidocrocite, and goethite (Senkayi et al., 1986; Frisbee and Hossner, 1995; Haney et al., 2006). Our results show that $\mathrm{NO}_{2}{ }^{-}$can function as an oxidant of siderite under anoxic conditions and produce lepidocrocite as the primary mineral, which coexisted with goethite (Fig. 3c). Lepidocrocite is metastable with respect to goethite (Schwertmann and Taylor, 1972; Ishikawa et al., 2005). It appears that poorly crystalline ferrihydrite formed in our experiments as a precursor to lepidocrocite based on the broad feature from 15 to $40^{\circ} 2 \theta$ after $24 \mathrm{~h}$ (Fig. 3b). These results suggest the following overall reaction to be operative under our experimental conditions:

$4 \mathrm{FeCO}_{3}(\mathrm{~s})+2 \mathrm{NO}_{2}+2 \mathrm{H}^{+}+\mathrm{H}_{2} \mathrm{O} \longleftrightarrow 4 \gamma-\mathrm{FeOOH}(\mathrm{s})+\mathrm{N}_{2} \mathrm{O}(\mathrm{g})+4 \mathrm{CO}_{2}(\mathrm{~g})$

It is possible that a homogeneous reaction involving dissolved $\mathrm{Fe}(\mathrm{II})$ in equilibrium with the solid $\mathrm{FeCO}_{3(\mathrm{~s})}$ and $\mathrm{NO}_{2}{ }^{-}$could occur in addition to the heterogeneous reaction with $\mathrm{FeCO}_{3(\mathrm{~s})}$. We tested this possibility by reacting $\mathrm{NO}_{2}{ }^{-}$with dissolved $\mathrm{Fe}$ (II) extracted from the dissolving $\mathrm{FeCO}_{3(\mathrm{~s})}$ mineral, referred to as "dissolved Fe(II)" in Fig. 2A. There was negligible reactivity in the reaction of $\mathrm{NO}_{2}{ }^{-}$with dissolved $\mathrm{Fe}(\mathrm{II})$ from the $\mathrm{FeCO}_{3(\mathrm{~s})}$ mineral within a period of $23 \mathrm{~h}$ (Fig. 2A). This suggests that structural $\mathrm{Fe}(\mathrm{II})$ in $\mathrm{FeCO}_{3(\mathrm{~s})}$ or adsorbed $\mathrm{Fe}(\mathrm{II})-\mathrm{FeCO}_{3(\mathrm{~s})}$ species are involved in reducing $\mathrm{NO}_{2}{ }^{-}$. 

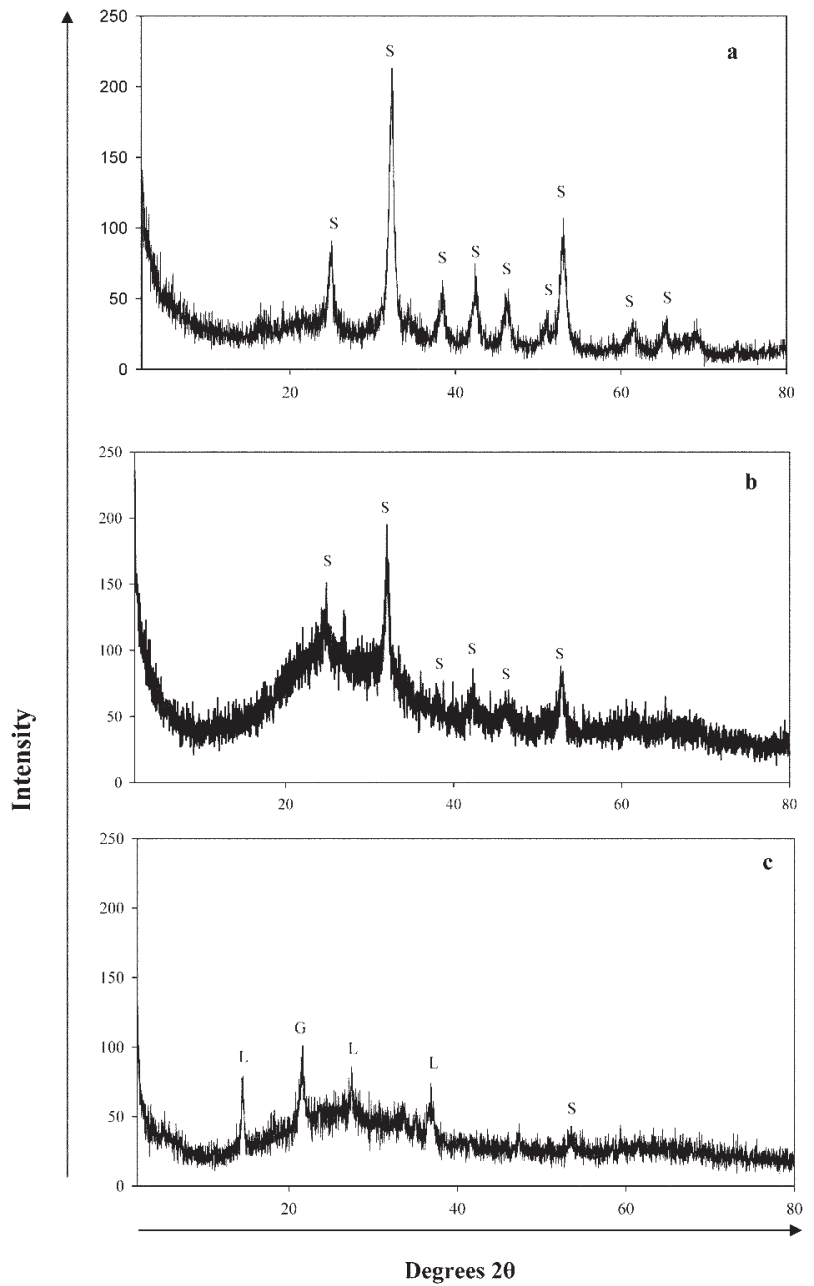

Fig. 3. X-ray diffraction patterns of the (a) control siderite after $96 \mathrm{~h}$, (b) siderite reacted with $4.6 \mathrm{mmol} \mathrm{L}^{-1} \mathrm{NO}_{2}{ }^{-}$after $24 \mathrm{~h}$, and (c) siderite reacted with $4.6 \mathrm{mmol} \mathrm{L}^{-1} \mathrm{NO}_{2}{ }^{-}$after $96 \mathrm{~h}$. Experiments were performed at pH 5.5. $\mathrm{S}=$ siderite, $\mathrm{L}=$ lepidocrocite, and $\mathrm{G}=$ goethite.

\section{Kinetic Analysis}

Kinetic data were analyzed using the method of initial rates and isolation (Lasaga, 1981). One can write the overall rate equation for $\mathrm{NO}_{2}^{-}$reduction by $\mathrm{FeCO}_{3(\mathrm{~s})}$ as

$$
-\frac{\mathrm{d}\left[\mathrm{NO}_{2}^{-}\right]_{\mathrm{T}}}{\mathrm{d} t}=k\left[\mathrm{FeCO}_{3(\mathrm{~s})}\right]^{x}\left[\mathrm{NO}_{2}^{-}\right]_{\mathrm{T}}^{y}
$$

where $-\left(\mathrm{d}\left[\mathrm{NO}_{2}^{-}\right]_{\mathrm{T}} / \mathrm{d} t\right)$ is the rate of disappearance of $\left[\mathrm{NO}_{2}{ }^{-}\right]$ $\mathrm{T}$, the sum of dissolved species of $\mathrm{NO}_{2}^{-} ; k$ is the overall rate coefficient; and $x$ and $y$ are reaction orders for $\mathrm{FeCO}_{3(\mathrm{~s})}$ and $\mathrm{NO}_{2}{ }^{-}$, respectively. The initial reaction rate was determined by regression analysis of the initial linear phase of $\left[\mathrm{NO}_{2}^{-}\right]_{\mathrm{T}}$ removal. For experiments where an excess of $\mathrm{NO}_{2}{ }^{-}$is present at $\mathrm{pH} 5.5$ and the initial concentration of $\mathrm{NO}_{2}{ }^{-}$is varied, Eq. [2] reduces to

$$
-\frac{\mathrm{d}\left[\mathrm{NO}_{2}^{-}\right]_{\mathrm{T}}}{\mathrm{d} t}=k_{\mathrm{I}}\left[\mathrm{NO}_{2}^{-}\right]_{\mathrm{T}}^{y}
$$

where $k_{\mathrm{I}}=k\left[\mathrm{FeCO}_{3(\mathrm{~s})}\right]^{x}$. Taking the logarithm of both sides of Eq. [3] allows one to calculate $y$, the reaction order for $\mathrm{NO}_{2}^{-}$, which is the slope of the least squares linear fit. In the same way, $\left[\mathrm{FeCO}_{3(\mathrm{~s})}\right]$ is varied at constant $\left[\mathrm{NO}_{2}^{-}\right]_{\mathrm{T}}$ and $\mathrm{pH}$ to calculate $x$.
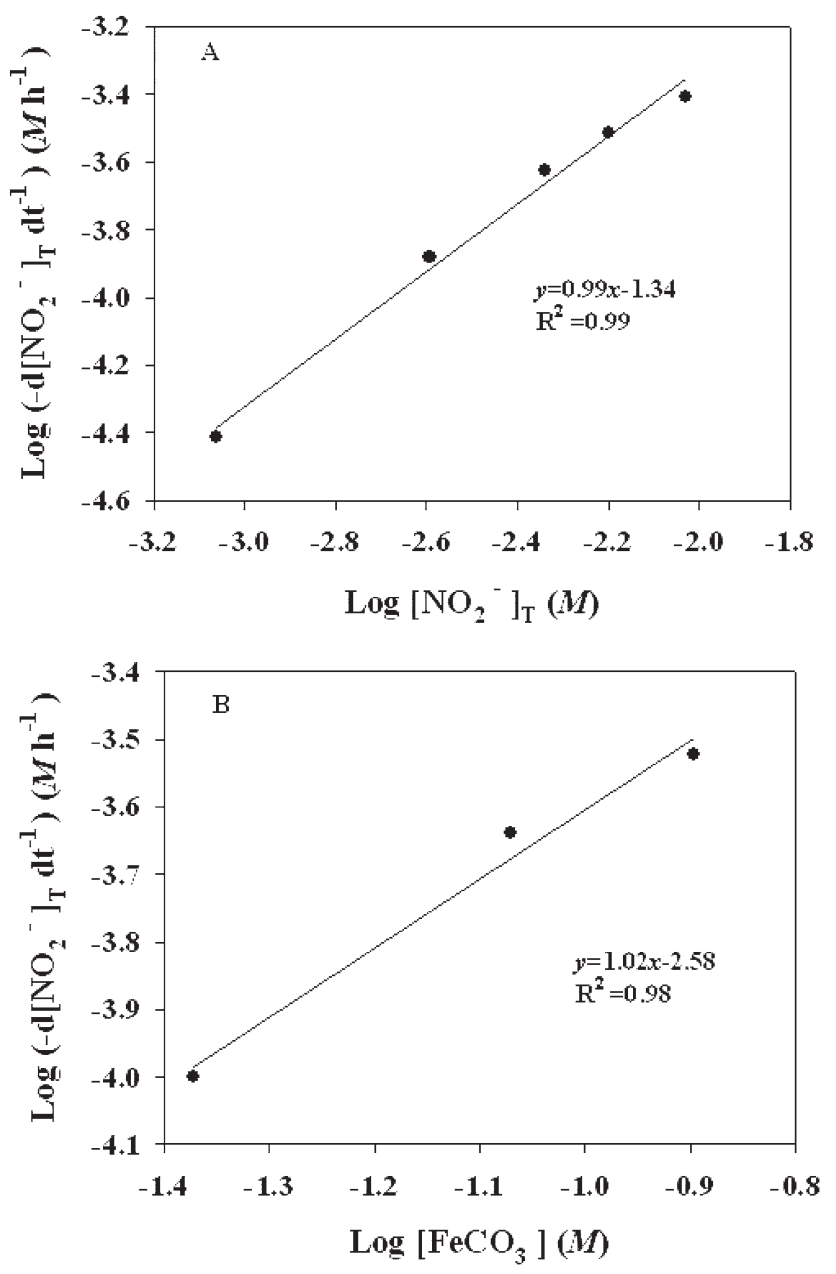

Fig. 4. Initial rate plots to determine apparent reaction order for (A) total $\mathrm{NO}_{2}^{-}$concentration $\left(\left[\mathrm{NO}_{2}^{-}\right]_{\mathrm{T}}\right)$ and $(\mathrm{B}) \mathrm{FeCO}_{3}$ concentration. The solid line represents a linear least square regression fit of the data.

There was a first-order dependence on $\left[\mathrm{NO}_{2}^{-}\right]_{\mathrm{T}}$ based on the slope of the regression, which is close to unity (Fig. 4A). These results differ from those of Hansen et al. (1994), where a zero-order dependence of $\mathrm{NO}_{2}{ }^{-}$was observed in the reduction by sulfate green rust. These differences may be explained by the differences in mineral structure. Sulfate green rust has a layered structure containing external and internal sites for $\mathrm{NO}_{2}^{-}$, with $\mathrm{SO}_{4}{ }^{2-}$ functioning as a charge-balancing interlayer anion (Hansen et al., 1994). Siderite, however, has a rhombohedral unit cell (Sharp, 1960) and possesses external reactive sites.

The reaction order for $\left[\mathrm{FeCO}_{3(\mathrm{~s})}\right]$ was $1.02 \pm 0.02$, which indicates a first-order dependence on $\mathrm{FeCO}_{3(\mathrm{~s})}$ (Fig. 4B). This implies a surface-controlled process and may be explained by the fact that at higher $\mathrm{FeCO}_{3(\mathrm{~s})}$ concentrations, more surface sites are available for reaction.

Thus, the reduction of $\mathrm{NO}_{2}^{-}$by siderite can be described by an overall second-order rate expression:

$$
\frac{-\mathrm{d}\left[\mathrm{NO}_{2}^{-}\right]_{\mathrm{T}}}{\mathrm{d} t}=k\left[\mathrm{FeCO}_{3(\mathrm{~s})}\right]^{1}\left[\mathrm{NO}_{2}^{-}\right]_{\mathrm{T}}^{1}
$$

The average rate coefficient $(k)$ calculated using Eq. [4] at $\mathrm{pH} 5.5$ for the $\mathrm{NO}_{2}{ }^{-}$and siderite concentration ranges used (0.83-9.3 and $42-120 \mathrm{mmol} \mathrm{L}^{-1}$, respectively) was $0.55 \pm 0.05 \mathrm{M}^{-1} \mathrm{~h}^{-1}$.

The reduction of $\mathrm{NO}_{2}^{-}$by siderite was $\mathrm{pH}$ dependent. The second-order rate coefficients increase threefold as $\mathrm{pH}$ 


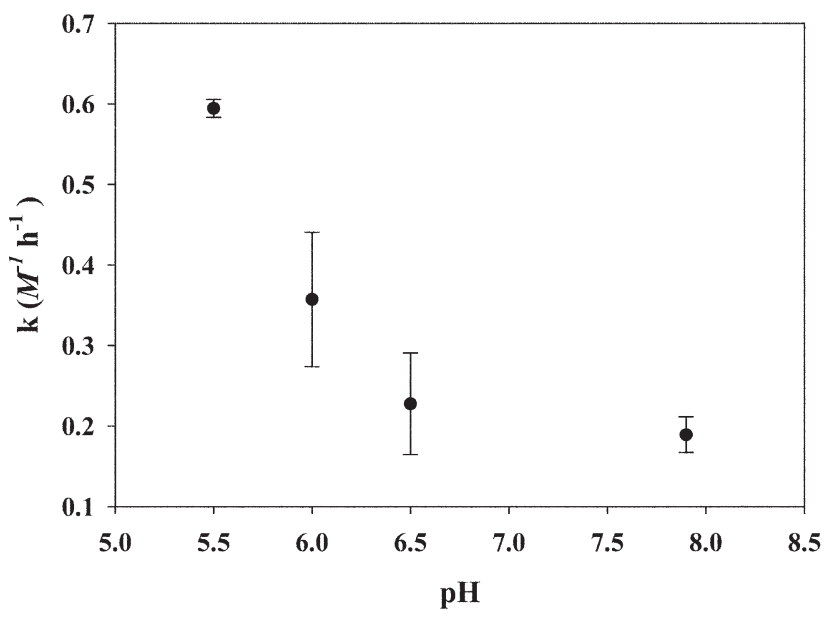

Fig. 5. Second-order rate coefficients for the reduction of $\mathrm{NO}_{2}{ }^{-}$by siderite at different $\mathrm{pH}$ values, for $10 \mathrm{~g} \mathrm{~L}^{-1}$ siderite and an initial $\mathrm{NO}_{2}{ }^{-}$concentration of $4.6 \mathrm{mmol} \mathrm{L}^{-1}$.

decreased from 7.9 to 5.5 (Fig. 5). The influence of $\mathrm{pH}$ can be rationalized on the basis of the relative distribution of siderite surface sites and $\mathrm{NO}_{2}{ }^{-}$speciation.

Siderite bears several types of surface sites in the presence of water, based on comparisons from its isostructural counterpart, calcite (Van Cappellen et al., 1993). In the presence of water, siderite forms two primary sites on the surface, $>\mathrm{FeOH}^{0}$ and $>\mathrm{CO}_{3} \mathrm{H}^{0}$ groups. The speciation of siderite surface sites has been described using the surface complexation model, where solution chemistry is related to surface complexes through equilibrium expressions (Van Cappellen et al., 1993; Pokrovsky and Schott, 2002). The $>\mathrm{FeOH}^{0}$ and $>\mathrm{CO}_{3} \mathrm{H}^{0}$ groups on the siderite surface undergo protonation and deprotonation reactions and are characterized by stability constants (Table 1). The total number of reactive sites for $>\mathrm{FeOH}^{0}$ groups, denoted as $[>\mathrm{Fe}]_{\mathrm{T}}$, is related to the sum of protonated and deprotonated surface species:

$[>\mathrm{Fe}]_{\mathrm{T}}=\left[>\mathrm{FeOH}^{0}\right]+\left[>\mathrm{FeO}^{-}\right]+\left[>\mathrm{FeOH}_{2}^{+}\right]+\left[>\mathrm{FeHCO}_{3}^{0}\right]+\left[>\mathrm{FeCO}_{3}^{-}\right]$

One can rearrange and express Eq. [5] in terms of $\left[>\mathrm{FeOH}^{0}\right]$ :

$$
\frac{\left[>\mathrm{FeOH}^{0}\right]}{[\mathrm{Fe}]_{\mathrm{T}}}=\frac{1}{1+\frac{K_{1}}{\left[\mathrm{H}^{+}\right]}+K_{2}\left[\mathrm{H}^{+}\right]+K_{3}\left[\mathrm{H}^{+}\right]^{2}\left[\mathrm{CO}_{3}^{2-}\right]+K_{4}\left[\mathrm{H}^{+}\right]\left[\mathrm{CO}_{3}^{2-}\right]}
$$

where $K_{1}$ to $K_{4}$ correspond to the stability constants for Reactions 1 to 4 (Table 1 ). Expressions can be derived for $\left[>\mathrm{FeO}^{-}\right],\left[>\mathrm{FeOH}_{2}{ }^{+}\right],\left[>\mathrm{FeHCO}_{3}{ }^{0}\right]$, and $\left[>\mathrm{FeCO}_{3}{ }^{-}\right]$using Eq. [5] and [6] combined with their corresponding mass action equations. The concentration of $\mathrm{CO}_{3}{ }^{2-}$ was calculated using MINEQL+ with the average of all alkalinity determinations, assuming a system closed with respect to atmospheric $\mathrm{CO}_{2}$. We assumed a value for $[>\mathrm{Fe}]_{\mathrm{T}}$ of $4 \times 10^{-4} \mathrm{~mol}$ sites $\mathrm{L}^{-1}$ based on crystallographic data as described by Wersin et al. (1989) under

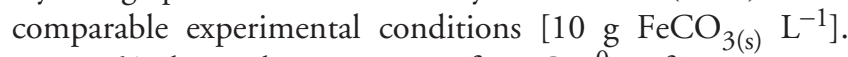
Figure 6A shows the speciation of $>\mathrm{FeOH}^{0}$ surface sites as a function of $\mathrm{pH}$. Under our experimental conditions of $\mathrm{pH}$ 5.5 to 7.9 , the $>\mathrm{FeHCO}_{3}{ }^{0}$ and $>\mathrm{FeOH}_{2}{ }^{+}$sites are dominant fractions, followed by $>\mathrm{FeCO}_{3}{ }^{-}$surface species (Fig. 6A). The $>\mathrm{FeOH}^{0}$ and $>\mathrm{FeO}^{-}$species do not become important until much greater $\mathrm{pH}$ values, as observed elsewhere (Van Cappellen et al., 1993; Pokrovsky and Schott, 2002). A similar approach
Table 1. Surface complexation reactions and corresponding stability constants $(K)$ considered in the siderite-water interface (temperature $T=298 \mathrm{~K}$, ionic strength $I=0$ ) $†$.

\begin{tabular}{cll}
$\begin{array}{c}\text { Reaction } \\
\text { no. }\end{array}$ & \multicolumn{1}{c}{ Reaction } & \multicolumn{1}{c}{ Log $\boldsymbol{K}$} \\
\hline 1 & $>\mathrm{FeOH}^{0} \leftrightarrow>\mathrm{FeO}^{-}+\mathrm{H}^{+}$ & -10.4 \\
2 & $>\mathrm{FeOH}^{0}+\mathrm{H}^{+} \leftrightarrow>\mathrm{FeOH}_{2}{ }^{+}$ & 10.2 \\
3 & $>\mathrm{FeOH}^{0}+\mathrm{CO}_{3}{ }^{2-}+2 \mathrm{H}^{+} \leftrightarrow>\mathrm{FeHCO}_{3}{ }^{0}+\mathrm{H}_{2} \mathrm{O}$ & 22.75 \\
4 & $>\mathrm{FeOH}^{0}+\mathrm{CO}_{3}{ }^{2-}+\mathrm{H}^{+} \leftrightarrow>\mathrm{FeCO}_{3}{ }^{-}+\mathrm{H}_{2} \mathrm{O}$ & 14.65 \\
5 & $>\mathrm{CO}_{3} \mathrm{H}^{0} \leftrightarrow>\mathrm{CO}_{3}{ }^{-}+\mathrm{H}^{+}$ & -4.4 \\
6 & $>\mathrm{CO}_{3} \mathrm{H}^{0}+\mathrm{Fe}^{2+} \leftrightarrow>\mathrm{CO}_{3} \mathrm{Fe}^{+}+\mathrm{H}^{+}$ & -1.6 \\
\hline+ Reactions from each site are located on the (104) plane (Pokrovsky and \\
\multicolumn{3}{r}{ Schott, 2002). }
\end{tabular}

was taken for the $>\mathrm{CO}_{3} \mathrm{H}^{0}$ surface sites using Reactions 5 and 6 (Table 1). Calculations for $>\mathrm{CO}_{3} \mathrm{Fe}^{+}$were based on mean solution $\mathrm{Fe}(\mathrm{II})$ concentrations measured in control bottles at pH 6 and 7.9. Figure 6B shows that negatively charged species, $>\mathrm{CO}_{3}{ }^{-}$sites, were predicted to be abundant, followed by $>\mathrm{CO}_{3} \mathrm{Fe}^{+}$and $>\mathrm{CO}_{3} \mathrm{H}^{0}$.

The speciation of dissolved $\mathrm{NO}_{2}^{-}$must be accounted for to help explain the $\mathrm{pH}$ dependence in its reduction rate. Total $\mathrm{NO}_{2}{ }^{-}$concentration $\left(\left[\mathrm{NO}_{2}{ }^{-}\right]_{\mathrm{T}}\right)$, which was measured in our experiments using ion chromatography, is the sum of protonated $\left(\mathrm{HNO}_{2}\right)$ and deprotonated $\left(\mathrm{NO}_{2}{ }^{-}\right)$forms and is expressed by the following mass balance expression:

$$
\left[\mathrm{NO}_{2}^{-}\right]_{\mathrm{T}}=\left[\mathrm{HNO}_{2}\right]+\left[\mathrm{NO}_{2}^{-}\right]
$$

Nitrite can undergo protonation and deprotonation reactions depending on $\mathrm{pH}$ :

$$
\mathrm{HNO}_{2} \leftrightarrow \mathrm{NO}_{2}^{-}+\mathrm{H}^{+} K_{\mathrm{a}}=5 \times 10^{-4}
$$

where $K_{\mathrm{a}}$ is the acid dissociation constant. Equations [7] and [8] can be rearranged to solve for $\left[\mathrm{HNO}_{2}\right]$ and $\left[\mathrm{NO}_{2}{ }^{-}\right]$as a function of $\mathrm{pH}$ :

$$
\left[\mathrm{NO}_{2}^{-}\right]_{\mathrm{T}}=\left[\mathrm{HNO}_{2}\right]\left(1+\frac{K_{\mathrm{a}}}{\left[\mathrm{H}^{+}\right]}\right)
$$

There are several possible combinations of precursor surface complexes that may form in the transition state between siderite surface sites and different chemical species of $\mathrm{NO}_{2}{ }^{-}$to explain the $\mathrm{pH}$ dependence in Fig. 5. Of the $>\mathrm{FeOH}^{0}$ surface sites, we assumed $>\mathrm{FeHCO}_{3}{ }^{0}$ and $>\mathrm{FeOH}_{2}{ }^{+}$to be most important based on their abundance (see Fig. 6A). The $>\mathrm{CO}_{3} \mathrm{Fe}^{+}$site, where $\mathrm{Fe}(\mathrm{II})$ is bound on $\mathrm{FeCO}_{3(s)}$, was considered because past studies have shown that $\mathrm{Fe}(\mathrm{II})$ bound on lepidocrocite was reactive toward $\mathrm{NO}_{2}{ }^{-}$(Sorensen and Thorling, 1991). In addition, the possibility of $>\mathrm{CO}_{3} \mathrm{Fe}^{+}$playing a role was suggested based on the lack of reaction between dissolved $\mathrm{Fe}$ (II) [in equilibrium with $\mathrm{FeCO}_{3(\mathrm{~s})}$ ] and $\mathrm{NO}_{2}^{-}$(see Fig. 2A).

Possible precursor surface complexes were calculated as a product of their concentrations and as a function of $\mathrm{pH}$ (Fig. 7). This approach has been used elsewhere to describe sulfide oxidation by $\mathrm{Fe}(\mathrm{III})$ and $\mathrm{Mn}$ (IV) minerals and assumes that precursor surface complexation is rate limiting (Yao and Millero, 1993; Poulton, 2003). The products $\left[>\mathrm{FeHCO}_{3}{ }^{0}\right]$ $\left[\mathrm{HNO}_{2}\right]$ and $\left[>\mathrm{CO}_{3} \mathrm{Fe}^{+}\right]\left[\mathrm{HNO}_{2}\right]$ sharply increased below $\mathrm{pH}$ 

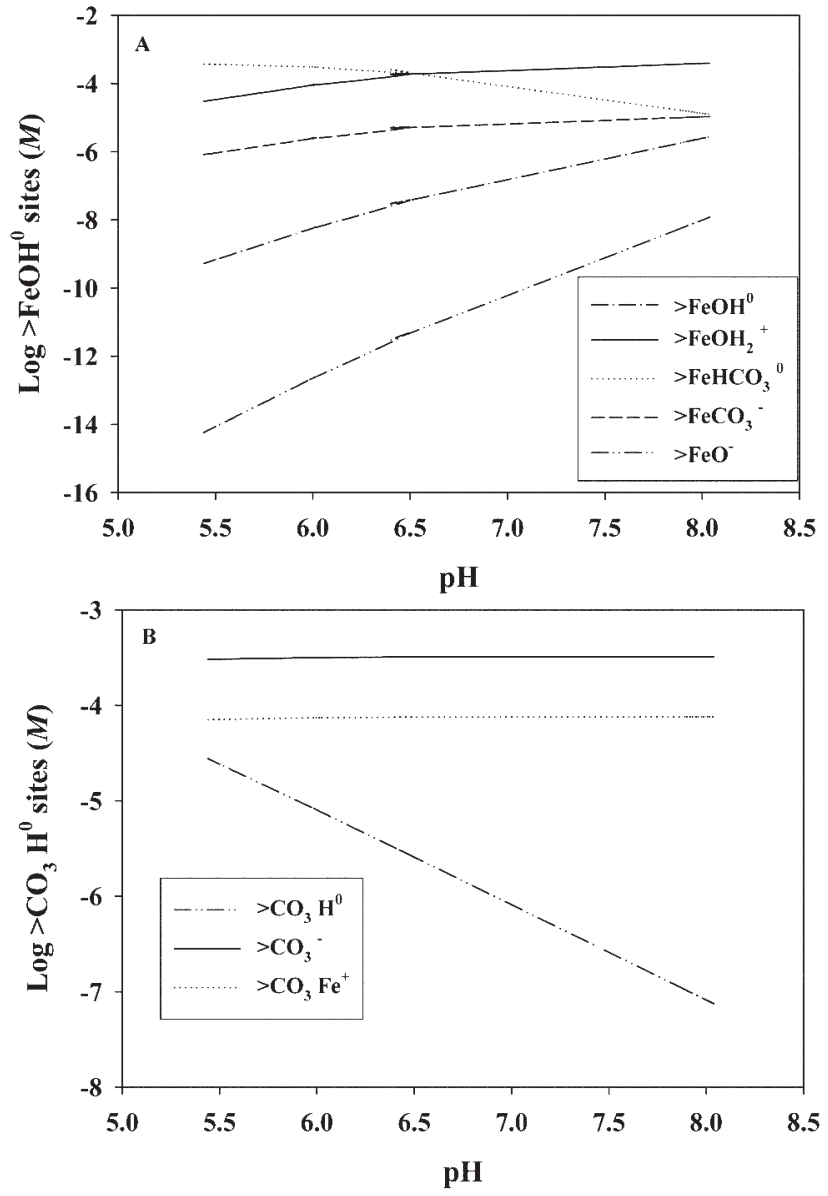

Fig. 6. The predicted surface speciation of $(\mathrm{A})>\mathrm{FeOH}^{0}$ and $(\mathrm{B})>\mathrm{CO}_{3} \mathrm{H}^{0}$ sites of siderite. Equilibrium constants were taken from Table 1.

6.5 (Fig. 7A and 7C), which is similar to the trend in the reaction rate (Fig. 5). The $\left[>\mathrm{FeHCO}_{3}{ }^{0}\right]\left[\mathrm{NO}_{2}{ }^{-}\right]$product increased with a decrease in $\mathrm{pH}$ as well and was in greater concentration than the other complexes (Fig. 7A, right-hand $y$ axis).

The $\left[>\mathrm{FeOH}_{2}{ }^{+}\right]\left[\mathrm{HNO}_{2}\right]$ form increased linearly with a decrease in $\mathrm{pH}$ (Fig. 7B). The $\mathrm{Fe}(\mathrm{II})-\mathrm{OH}_{2}$ bond is labile and would result in dissociation of $\mathrm{H}_{2} \mathrm{O}$. In solution chemistry, the water exchange rate for hexaaquo $\mathrm{Fe}(\mathrm{II})\left[\mathrm{Fe}\left(\mathrm{H}_{2} \mathrm{O}\right)_{6(\mathrm{aq})}{ }^{2+}\right]$ is rapid, estimated to be $3.2 \times 10^{6} \mathrm{~s}^{-1}$ (Shriver et al., 1994). The $\mathrm{HNO}_{2}$ could bond directly to an exposed $\mathrm{Fe}$ (II) surface site and undergo electron transfer reactions. It is probable that the bonding mode of $\mathrm{HNO}_{2}$ on $\mathrm{Fe}(\mathrm{II})$ is by the $\mathrm{N}$ atom, because this forms a stronger complex (Hitchman and Rowbottom, 1982; Shriver et al., 1994; Figgis and Hitchman, 2000). This configuration would allow the $\mathrm{HNO}_{2}$ to serve as a $\pi$ acceptor; thus, it would be able to accept electron density from the $\pi$ system of $\mathrm{Fe}$ (II) (Luther et al., 1992).

The variations in $\left[>\mathrm{FeOH}_{2}^{+}\right]\left[\mathrm{NO}_{2}^{-}\right]$and $\left[>\mathrm{CO}_{3} \mathrm{Fe}^{+}\right]$ $\left[\mathrm{NO}_{2}{ }^{-}\right]$are sensitive to $\mathrm{pH}$, but in the opposite direction to the reaction rate (compare Fig. 5 with Fig. $7 \mathrm{~B}$ and $7 \mathrm{C}$ ). Therefore, they were ruled out as possible precursor surface complexes.

It is noteworthy that three out of the four possible precursor surface complexes $\left(\left[>\mathrm{FeHCO}_{3}{ }^{0}\right]\left[\mathrm{HNO}_{2}\right],\left[>\mathrm{FeOH}_{2}{ }^{+}\right]\right.$ $\left[\mathrm{HNO}_{2}\right]$, and $\left.\left[>\mathrm{CO}_{3} \mathrm{Fe}^{+}\right]\left[\mathrm{HNO}_{2}\right]\right)$ involve $\mathrm{HNO}_{2}$. Nitrous acid is a reactive oxidant toward Fe(II) species in solution. For example, oxidation of solution Fe(II) complexed with ethylenediaminetetraacetate exhibited a sharp increase in reaction
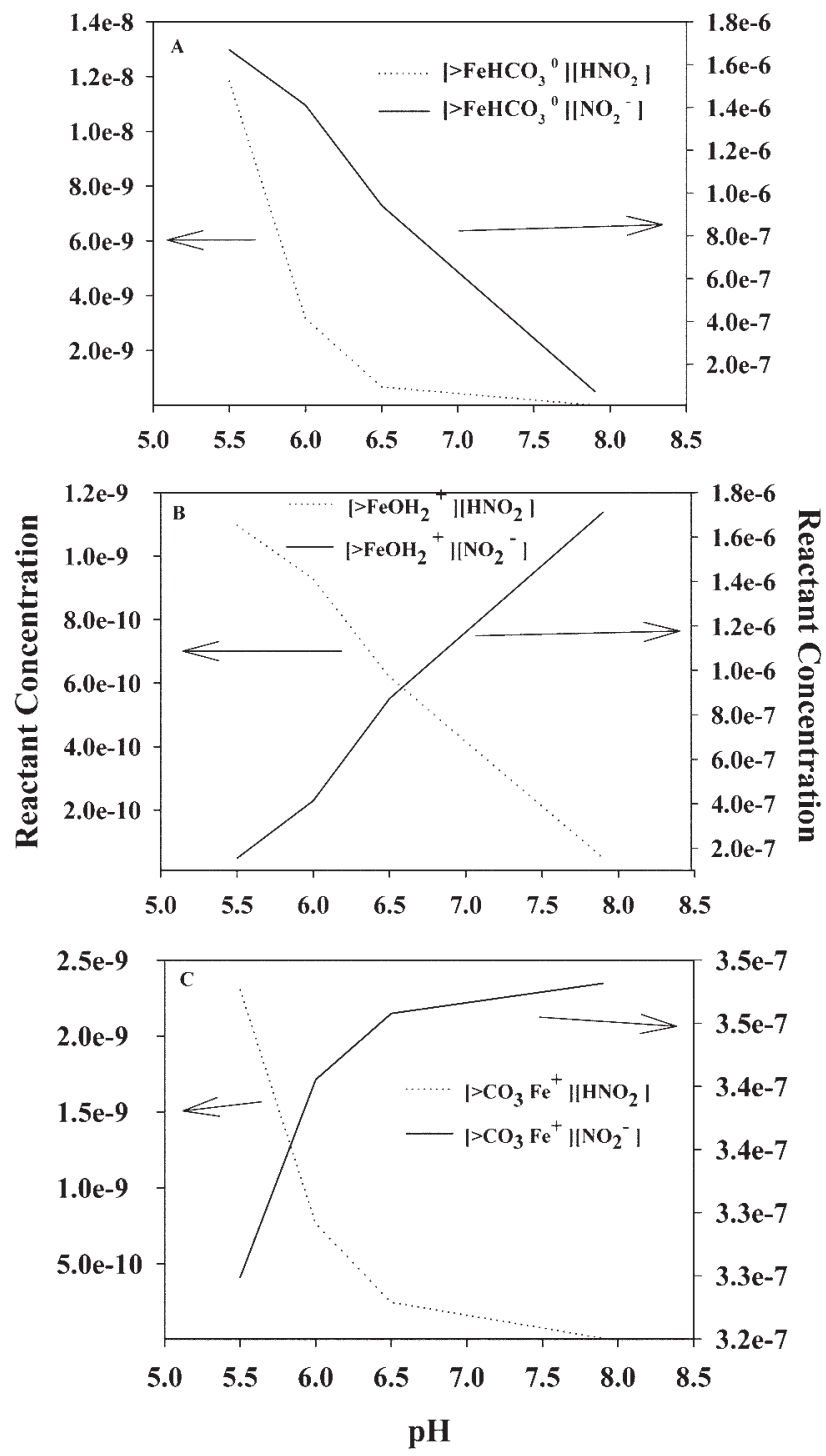

Fig. 7. Possible precursor surface complexes as a product of their concentrations and as a function of $\mathrm{pH}$ for (A) $\left[>\mathrm{FeHCO}_{3}{ }^{0}\right]\left[\mathrm{HNO}_{2}\right]$ and $\left[>\mathrm{FeHCO}_{3}{ }^{0}\right]\left[\mathrm{NO}_{2}{ }^{-}\right] ;$(B) $\left[>\mathrm{FeOH}_{2}{ }^{+}\right]\left[\mathrm{HNO}_{2}\right]$ and $\left[>\mathrm{FeOH}_{2}{ }^{+}\right]$ $\left[\mathrm{NO}_{2}{ }^{-}\right]$; and $(\mathrm{C})\left[>\mathrm{CO}_{3} \mathrm{Fe}^{+}\right]\left[\mathrm{HNO}_{2}\right]$ and $\left[>\mathrm{CO}_{3} \mathrm{Fe}^{+}\right]\left[\mathrm{NO}_{2}{ }^{-}\right]$.

rate with a decrease in $\mathrm{pH}$. Kinetic modeling of the rate data revealed a second-order dependence on $\mathrm{HNO}_{2}$ concentration (Zang et al., 1988). Protonation on the $\mathrm{O}$ weakens the $\mathrm{N}-\mathrm{O}$ bond, allowing it to break (Shriver et al., 1994). Although $\left[\mathrm{HNO}_{2}\right]$ comprises only a small percentage of $\left[\mathrm{NO}_{2}{ }^{-}\right]_{\mathrm{T}}$ even at the lowest experimental $\mathrm{pH}$ of $5.5(\sim 0.7 \%)$, our data suggest that it is an important species kinetically.

Nitrite reduction by $\mathrm{FeCO}_{3(s)}$ is a secondary reaction in the overall process of $\mathrm{NO}_{3}{ }^{-}$-dependent $\mathrm{Fe}$ (II) oxidation, a process relevant in environments where $\mathrm{NO}_{3}{ }^{-}$- and $\mathrm{Fe}(\mathrm{III})-$ reducing zones overlap or across aerobic-anaerobic interfaces. These environments could be present in poorly drained soils containing a shallow fragipan or in freshwater wetlands. Further experiments in our lab showed that $\mathrm{NO}_{3}{ }^{-}$reactivity was negligible with $\mathrm{FeCO}_{3(\mathrm{~s})}$ for time periods up to 30 d (data not shown), despite the favorable thermodynamics (Fig. 1). Thus, where fertilizer $\mathrm{NO}_{3}{ }^{-}$is added to soil under $\mathrm{Fe}(\mathrm{III})$-reducing conditions [where $\mathrm{FeCO}_{3(\mathrm{~s})}$ controls $\mathrm{Fe}(\mathrm{II})$ solubility], it is probable that bacteria containing the nitrate 
reductase enzyme would catalyze the first step of $\mathrm{NO}_{3}{ }^{-}$reduction to $\mathrm{NO}_{2}^{-}$(Sorensen, 1982; Matocha and Coyne, 2007). Subsequently, $\mathrm{FeCO}_{3(\mathrm{~s})}$ would readily reduce $\mathrm{NO}_{2}^{-}$to $\mathrm{N}_{2} \mathrm{O}$. Interestingly, $\mathrm{NO}_{2}{ }^{-}$was not detected as an intermediate in the overall process of $\mathrm{NO}_{3}{ }^{-}$-dependent $\mathrm{Fe}$ (II) oxidation in a field soil amended with $\mathrm{NO}_{3}{ }^{-}$(Matocha and Coyne, 2007). This could be due to rapid secondary chemical reduction of $\mathrm{NO}_{2}{ }^{-}$ by $\mathrm{FeCO}_{3(s)}$.

The abiotic production of $\mathrm{N}_{2} \mathrm{O}$ during $\mathrm{NO}_{2}{ }^{-}$reduction by $\mathrm{FeCO}_{3(\mathrm{~s})}$ is significant because it is an important trace gas involved in global warming and depletion of the ozone layer (Galloway et al., 2003). There has been an increase in global $\mathrm{N}_{2} \mathrm{O}$ emissions, with a significant part of the increase attributed to direct emissions from agricultural soils (Mosier et al., 1998). The rate expression derived from this study represents an important first step in modeling $\mathrm{N}_{2} \mathrm{O}$ production in $\mathrm{Fe}$ (III)-reducing soil where fertilizer $\mathrm{NO}_{3}{ }^{-}$is applied and where $\mathrm{FeCO}_{3(\mathrm{~s})}$ controls $\mathrm{Fe}(\mathrm{II})$ solubility. The exact mechanism of $\mathrm{NO}_{2}{ }^{-}$reduction by $\mathrm{FeCO}_{3(\mathrm{~s})}$ remains to be established.

During the reduction of $\mathrm{NO}_{2}^{-}, \mathrm{FeCO}_{3(\mathrm{~s})}$ is oxidized to $\gamma-\mathrm{FeOOH}_{(s)}$. This is significant because it represents an anoxic pathway to mineral $\mathrm{Fe}(\mathrm{III})$ production and could impact the behavior of other nutrients such as phosphate, a well-known adsorbate to mineral $\mathrm{Fe}(\mathrm{III})$ surfaces (Essington, 2004). In addition, the anoxic production of $\gamma-\mathrm{FeOOH}_{(\mathrm{s})}$ would contribute to the inhibition in $\mathrm{Fe}$ (III) reduction, a phenomenon that has been reported elsewhere (Obuekwe et al., 1981; Lovley, 2000).

\section{CONCLUSIONS}

The reduction of $\mathrm{NO}_{2}^{-}$by siderite occurred readily. The main products of the reaction were $\mathrm{N}_{2} \mathrm{O}$ and a solid $\mathrm{Fe}(\mathrm{III})$ mineral (lepidocrocite). The empirical rate expression was first order in each reactant. The second-order rate coefficients increased threefold as the $\mathrm{pH}$ decreased from 7.9 to 5.5. Although the second-order rate expression suggests that a bimolecular process is involved in the rate-limiting step, it is a composite expression and reflects the contribution of several possible combinations of siderite surface sites $\left(>\mathrm{FeHCO}_{3}{ }^{0}\right.$, $>\mathrm{FeOH}_{2}{ }^{+}$, and $>\mathrm{CO}_{3} \mathrm{Fe}^{+}$) with reactive $\mathrm{NO}_{2}{ }^{-}$species $\left(\left[\mathrm{HNO}_{2}\right]\right)$. Additional experiments are needed to elucidate the structure of the activated complex between siderite surface sites and incoming $\mathrm{NO}_{2}^{-}$. An example of an environment where this process may occur would be in overlapping $\mathrm{NO}_{3}{ }^{-}$- and $\mathrm{Fe}(\mathrm{III})$-reducing zones where $\mathrm{Fe}(\mathrm{II})$ accumulates and reprecipitates as siderite and encounters $\mathrm{NO}_{2}{ }^{-}$produced from fertilizer $\mathrm{NO}_{3}{ }^{-}$applications.

\section{ACKNOWLEDGMENTS}

This project was supported by National Research Initiative Competitive Grant no. 2002-35107-12214 from the USDA Cooperative State Research, Education, and Extension Service.

\section{REFERENCES}

Alowitz, J.M., and M.M. Scherer. 2002. Kinetics of nitrate, nitrite, and Cr(VI) reduction by iron metal. Environ. Sci. Technol. 36:299-306.

Bard, A.J., R. Parsons, and J. Jordan. 1985. Standard potentials in aqueous solution. Marcel Dekker, New York.

Bartlett, R.J. 1981. Nonmicrobial nitrite-to-nitrate transformation in soils. Soil Sci. Soc. Am. J. 45:1054-1058.

Cleemput, O.V., and L. Baert. 1983. Nitrite stability influenced by iron compounds. Soil Biol. Biochem. 15:137-140.

Coleman, M.L., D.B. Hedrick, D.R. Lovely, D.C. White, and K. Pye. 1993. Reduction of $\mathrm{Fe}(\mathrm{II})$ in sediments by sulphate-reducing bacteria. Nature 361:436-438.

Cooper, D.C., F.W. Picardel, A. Schimmelmann, and A.J. Coby. 2003. Chemical and biological interactions during nitrate and goethite reduction by Shewanella putrefaciens 200. Appl. Environ. Microbiol. 69:3517-3525.

DiChristina, T.J. 1992. Effects of nitrate and nitrite on dissimilatory iron reduction by Shewanella putrefaciens 200. J. Bacteriol. 174:1891-1896.

Duckworth, O.W., and S.T. Martin. 2004. Role of molecular oxygen in the dissolution of siderite and rhodochrosite. Geochim. Cosmochim. Acta 68:607-621.

Essington, M.E. 2004. Soil and water chemistry: An integrative approach. CRC Press, Boca Raton, FL.

Favre, F., D. Tessier, M. Abdelmoula, J.M. Génin, W.P. Gates, and P. Boivin. 2002. Iron reduction and changes in cation exchange capacity in intermittently waterlogged soil. Eur. J. Soil Sci. 53:175-183.

Figgis, B.N., and M.A. Hitchman. 2000. Ligand field theory and its applications. Wiley-VCH, New York.

Fredrickson, J.K., J.M. Jachara, D.W. Kennedy, H. Dong, T.C. Onstott, N.W. Hinman, and S. Li. 1998. Biogenic iron mineralization accompanying the dissimilatory reduction of hydrous ferric oxide by groundwater bacterium. Geochim. Cosmochim. Acta 62:3239-3257.

Frisbee, N.M., and L.R. Hossner. 1995. Siderite weathering in acidic solutions under carbon dioxide, air, and oxygen. J. Environ. Qual. 24:856-860.

Galloway, J.N., J.D. Aber, J.W. Erisman, S.P. Seitzinger, R.W. Howarth, E.B. Cowling, and B.J. Cosby. 2003. The nitrogen cascade. Bioscience 53:341-356.

Haney, E.B., R.L. Haney, L.R. Hossner, and G.N. White. 2006. Neutralization potential determination of siderite $\left(\mathrm{FeCO}_{3}\right)$ using selected oxidants. J. Environ. Qual. 35:871-879.

Hansen, H.C.B., O.K. Borggaard, and J. Sørensen. 1994. Evaluation of the free energy of formation of $\mathrm{Fe}(\mathrm{II})-\mathrm{Fe}$ (III) hydroxide-sulfate (green rust) and its reduction of nitrite. Geochim. Cosmochim. Acta 58:2599-2608.

Hitchman, M.A., and G.L. Rowbottom. 1982. Transition metal nitrite complexes. Coord. Chem. Rev. 42:55-132.

Ishikawa, T., K. Takeuchi, K. Kandori, and T. Nakayama. 2005. Transformation of $\gamma$-FeOOH to $\alpha-\mathrm{FeOOH}$ in acidic solutions containing metal ions. Colloids Surf. A 266:155-159.

Jambor, J.L., J.E. Dutrizac, M. Raudsepp, and L.A. Groat. 2003. Effect of peroxide on neutralization-potential values of siderite and other carbonate minerals. J. Environ. Qual. 32:2373-2378.

Komatsu, Y., M. Takagi, and M. Yamaguchi. 1978. Participation of iron in denitrification in waterlogged soil. Soil Biol. Biochem. 10:21-26.

Lasaga, A.C. 1981. Rate laws of chemical reactions. Rev. Mineral. 8:1-68.

Lovley, D.R. 2000. Fe(III) and Mn(IV) reduction. p. 3-30. In D.R. Lovley (ed.) Environmental microbe-metal interactions. ASM Press, Washington, DC.

Luther, G.W., III, J.E. Kostka, T.M. Church, B. Sulzberger, and W. Stumm. 1992. Seasonal iron cycling in the salt marsh sedimentary environment: The importance of ligand complexes with $\mathrm{Fe}$ (II) and $\mathrm{Fe}$ (III) in the dissolution of $\mathrm{Fe}(\mathrm{III})$ minerals and pyrite, respectively. Mar. Chem. 40:81-103.

Matocha, C.J., and M.S. Coyne. 2007. Short-term response of soil iron to nitrate addition. Soil Sci. Soc. Am. J. 71:108-117.

McMillan, S.G., and U. Schwertmann. 1998. Morphological and genetic relations between siderite, calcite, and goethite in a Low Moor Peat from southern Germany. Eur. J. Soil Sci. 49:283-293.

Moraghan, J.T., and R.J. Buresh. 1977. Chemical reduction of nitrite and nitrous oxide by ferrous iron. Soil Sci. Soc. Am. J. 41:47-49.

Mosier, A.R., C. Kroeze, C. Nevison, O. Oenema, S. Seitziner, and O. Van Cleemput. 1998. Closing the global atmospheric $\mathrm{N}_{2} \mathrm{O}$ budget: Nitrous oxide emissions through the agricultural nitrogen cycle. Nutr. Cycling Agroecosyst. 52:225-248.

Ngo, T.T., A.P.H. Pan, C.F. Yam, and H.M. Lenhoff. 1982. Interference in determination of ammonia with the hypochlorite-alkaline phenol method of Berthelot. Anal. Chem. 54:46-49.

Obuekwe, C.O., D.W.S. Westlake, and F.D. Cook. 1981. Effect of nitrate on reduction of ferric iron by a bacterium isolated from crude oil. Can. J. Microbiol. 27:692-697.

Pokrovsky, O.S., and J. Schott. 2002. Surface chemistry and dissolution kinetics of divalent metal carbonates. Environ. Sci. Technol. 36:426-432. 
Postma, D. 1982. Pyrite and siderite formation in brackish and freshwater swamp sediments. Am. J. Sci. 282:1151-1183.

Poulton, S.W. 2003. Sulfide oxidation and iron dissolution kinetics during the reaction of dissolved sulfide with ferrihydrite. Chem. Geol. 202:79-94.

Rakshit, S., C.J. Matocha, and G.R. Haszler. 2005. Nitrate reduction in the presence of wüstite. J. Environ. Qual. 34:1286-1292.

Ratering, S., and S. Schnell. 2000. Localization of iron-reducing activity in paddy soil by profile studies. Biogeochemistry 48:341-365.

Schecher, W., and D.C. McAvoy. 1998. MINEQL+Version 4.5. Environmental Research Software, Hallowell, ME.

Schwertmann, U., and R.M. Taylor. 1972. The transformation of lepidocrocite to goethite. Clays Clay Miner. 20:151-158.

Senkayi, A.L., J.B. Dixon, and L.R. Hossener. 1986. Todorokite, goethite, and hematite: Alteration product of siderite in East Texas lignite overburden. Soil Sci. 142:36-42.

Senko, J.M., Y. Mohamed, T. Dewers, and L.R. Krumholz. 2005. Role for $\mathrm{Fe}(\mathrm{III})$ minerals in nitrate-dependent microbial U(IV) oxidation. Environ. Sci. Technol. 39:2529-2536.

Sharp, W.E. 1960. The cell constants of artificial siderite. Am. Mineral. 45:241-243.

Shriver, D.F., P. Atkins, and C.H. Langford. 1994. Inorganic chemistry. 2nd ed. W.H. Freeman and Co., New York.

Sorensen, J. 1982. Reduction of ferric iron in anaerobic, marine sediment and interaction with reduction of nitrate and sulfate. Appl. Environ. Microbiol. 43:319-324.

Sorensen, J., and L. Thorling. 1991. Stimulation by lepidocrocite $(\gamma-\mathrm{FeOOH})$ of $\mathrm{Fe}(\mathrm{II})$-dependent nitrite reduction. Geochim. Cosmochim. Acta 55:1289-1294.

Stookey, L.L. 1970. Ferrozine: A new spectrometric reagent for iron. Anal. Chem. 42:779-781.

Suess, E. 1979. Mineral phases formed in anoxic sediments by microbial decomposition of organic matter. Geochim. Cosmochim. Acta 43:339-352.

Thamdrup, B., K. Finster, J.W. Hansen, and F. Bak. 1993. Bacterial disproportionation of elemental sulfur coupled to chemical reduction of iron or manganese. Appl. Environ. Microbiol. 59:101-108.

Thornber, M.R., and E.H. Nickel. 1976. Supergene alteration of sulphides: III. The composition of associated carbonates. Chem. Geol. 17:45-72.

Van Cappellen, P., L. Charlet, W. Stumm, and P. Wersin. 1993. A surface complexation model of the carbonate mineral-aqueous solution interface. Geochim. Cosmochim. Acta 57:3505-3518.

Weber, K.A., L.A. Achenbach, and J.D. Coates. 2006. Microorganisms pumping iron: Anaerobic microbial iron oxidation and reduction. Nat. Rev. Microbiol. 4:752-764.

Wersin, P., L. Charlet, R. Karthein, and W. Stumm. 1989. From adsorption to precipitation: Sorption of $\mathrm{Mn}^{2+}$ on $\mathrm{FeCO}_{3(s)}$. Geochim. Cosmochim. Acta 53:2787-2796.

Wilkin, R.T., C. Su, R.G. Ford, and C.J. Paul. 2005. Chromium-removal processes during groundwater remediation by zerovalent iron permeable reactive barrier. Environ. Sci. Technol. 39:4599-4605.

Williams, A.G.B., K.B. Gregory, G.F. Parkin, and M.M. Sherer. 2005. Hexahydro-1,3,5-trinitro-1,3,5-triazine transformation by biologically reduced ferrihydrite: Evolution of Fe mineralogy, surface area, and reaction rates. Environ. Sci. Technol. 39:5183-5189.

Yao, W., and F.J. Millero. 1993. The rate of sulfide oxidation by $\delta-\mathrm{MnO}_{2}$ in seawater. Geochim. Cosmochim. Acta 57:3359-3365.

Zachara, J.M., J.K. Frederickson, S. Li, D.W. Kennedy, S.C. Smith, and P.L. Gassman. 1998. Bacterial reduction of crystalline $\mathrm{Fe}^{3+}$ oxides in single phase suspensions and subsurface materials. Am. Mineral. 83:1426-1443.

Zang, V., M. Kotowski, and R. van Eldik. 1988. Kinetics and mechanism of the formation of $\mathrm{Fe}^{\mathrm{II}}\left(\right.$ edta) $\mathrm{NO}$ in the system $\mathrm{Fe}^{\mathrm{II}}($ edta)/NO/HONO/ $\mathrm{NO}_{2}{ }^{-}$in aqueous solutions. Inorg. Chem. 27:3279-3283. 